\title{
Nucleotide-Binding Oligomerization Domain-Like Receptors and Inflammasomes in the Pathogenesis of Non-Microbial Inflammation and Diseases
}

\author{
D. Randal Mason Paul L. Beck Daniel A. Muruve \\ Department of Medicine, Immunology Research Group and the Institute of Infection, Immunity and Inflammation, \\ University of Calgary, Calgary, Alta., Canada
}

\begin{abstract}
Key Words
Nucleotide-binding oligomerization domain-like receptor • Inflammasome • Non-microbial inflammation •

Chronic disease
\end{abstract}

\begin{abstract}
The nucleotide-binding oligomerization domain (NOD)-like receptor (NLR) or nucleotide-binding domain leucine-rich repeat-containing family of genes plays an important role in the development of innate immune responses. Some family members are known to form multiprotein complexes known as inflammasomes that regulate the processing and secretion of proinflammatory mediators, such as interleukin-1 $\beta$ and interleukin-18. Activity of the inflammasome is triggered not only by microbial infection, but also by a wide range of both exogenous and endogenous noninfectious stimuli. Consequently, the dysregulation of inflammasome activity is associated with numerous proinflammatory, nonmicrobial human diseases. The discovery of NLRP3 gene mutations in autoinflammatory diseases such as Muckle-Wells syndrome has led to the association of NLRs in the pathogenesis of many non-microbial diseases that include arthritis, neurodegenerative disorders, metabolic disorders (obesity and diabetes), cardiovascular disease (atherosclerosis, myocardial infarction), inflammatory bowel disease, kidney disease and hypersensitivity dermatitis. A number of NLRs are also associated with human disease in the absence of inflammasome activity, suggesting additional roles for NLRs
\end{abstract}

in the regulation of inflammation and disease. This review serves to provide a summary of NLR-associated diseases and, where possible, the mechanisms behind the associations.

Copyright $\odot 2011$ S. Karger AG, Basel

\section{Introduction}

Interest in the nucleotide-binding oligomerization domain (NOD)-like receptor (NLR) or nucleotide-binding domain leucine-rich repeat-containing family of genes by both researchers and clinicians is evident by the hundreds of articles published on the topics of NLR structure, function and impact on human pathologies over the past decade. With ongoing discovery and classification, extensive effort has been put forth to understand how this family of proteins modulates inflammatory processes and directs both innate and adaptive responses.

Most pattern recognition receptors including Toll-like receptors (TLRs), RIG-like receptors and C-type lectin receptors are recognized for their ability to initiate immune responses to infections following activation by pathogen-associated molecular patterns (PAMPs). While PAMPs can also activate NLRs, many of these genes act as cytosolic innate sensors to damage/danger-associated molecular patterns (DAMPs) that include a wide range of noninfectious, environmental and host-derived stimuli. As such, the NLRs are capable of initiating and sustaining strong inflammatory responses to tissue damage or other

\section{KARGER \\ Fax +41613061234 \\ E-Mail karger@karger.ch}

www.karger.com
(C) 2011 S. Karger AG, Basel

$1662-811 \mathrm{X} / 12 / 0041-0016 \$ 38.00 / 0$

Accessible online at:

www.karger.com/jin
Dr. Daniel A. Muruve

Department of Medicine, Immunology Research Group

Institute of Infection, Immunity and Inflammation, University of Calgary

3330 Hospital Dr. NW, Calgary, AB T2N 4N1 (Canada)

Tel. +1 403220 2418, E-Mail dmuruve@ ucalgary.ca 
Table 1. Domain structures and general function of NLR family members

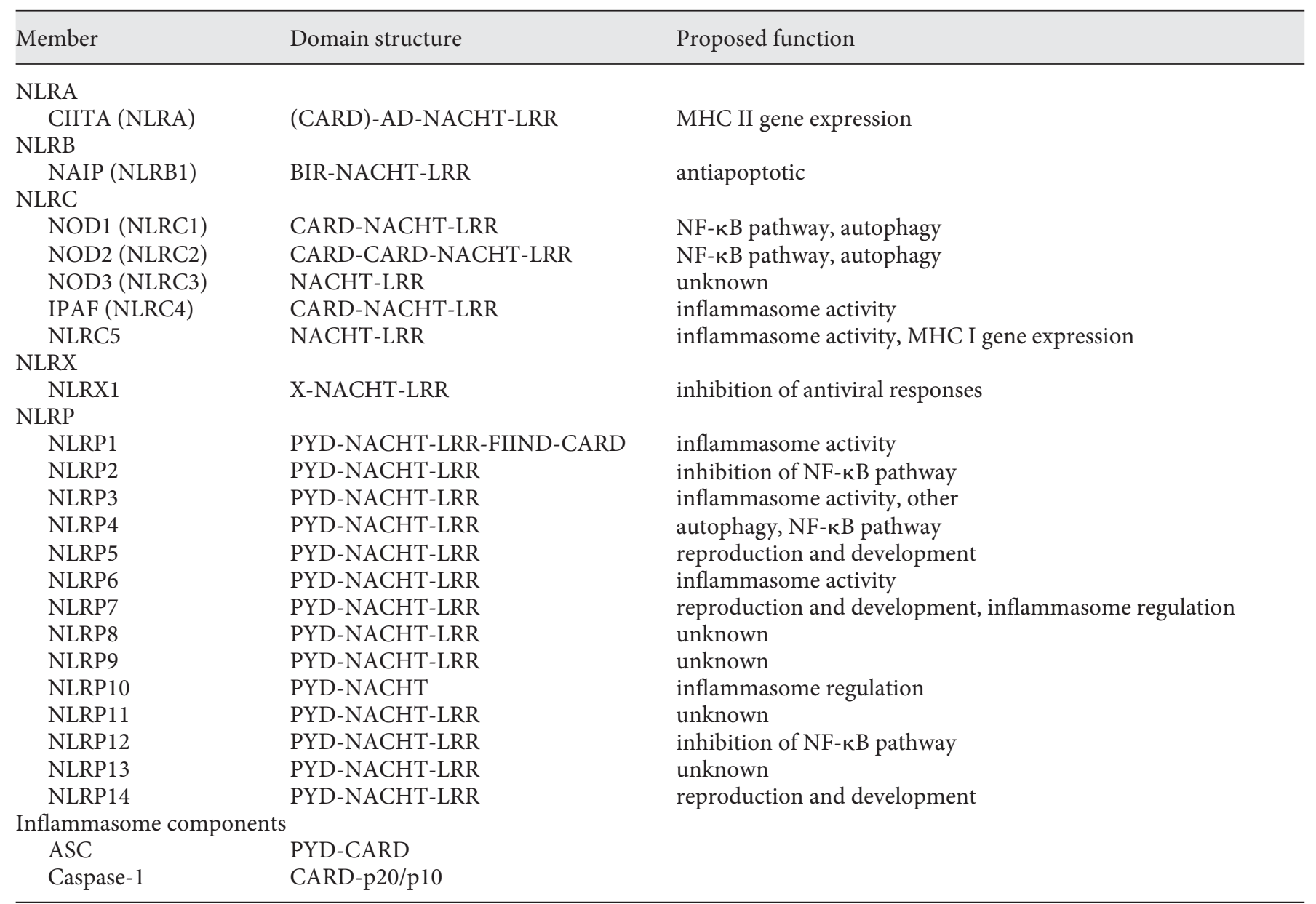

CIITA = Class II, major histocompatibility complex, transactivator; CARD = caspase recruitment domain; $\mathrm{AD}=$ acidic activation domain; $\mathrm{MHC}=$ major histocompatibility complex; $\mathrm{NF}-\kappa \mathrm{B}=$ nuclear factor $-\kappa \mathrm{B}$; FIIND = domain with function to find; $\mathrm{X}=\mathrm{X}$ domain; P20/P10 = capsase- 1 catalytic subunits.

pathophysiologic perturbations that are central to the pathogenesis of many common non-microbial diseases. This review serves to outline the role of NLRs in autoinflammatory, autoimmune, degenerative and other noninfectious disorders.

\section{The NLR Family of Genes}

The NLR family was discovered through genome mining that revealed 22 related human NLR genes [1]. The NLRs are a class of cytosolic innate sensors, with most sharing a conserved tripartite structure consisting of an $\mathrm{N}$-terminal caspase recruitment domain (CARD) or pyrin domain (PYD), followed by a central nucleotide- binding (NACHT) domain and a C-terminal leucine-rich repeat (LRR) domain. The CARD and PYD are known sites of protein-protein interactions, while the LRR domain is thought to play a role in ligand sensing and autoregulation. The NACHT domain is named after the four proteins for which this domain was initially characterized (NAIP, CIITA, HET-E and TP1) and functions as an NTPase with preferential affinity for ATP and GTP. This NTPase activity is involved in the capacity of NLRs to assume an active state capable of oligomerization [2].

The NLRs are categorized based on conserved N-terminal domains or on phylogenetic similarities (table 1). In the former, genes are group based on the presence of $\mathrm{N}$-terminal domains that include PYD, CARD, baculovirus inhibitory repeat-like (BIR) or acidic transactiva- 
Fig. 1. a Overview of inflammasome regulation and activation. b Inflammasomeindependent NLR functions. RLR = RIGlike receptor; $\mathrm{MHC}=$ major histocompatibility complex.

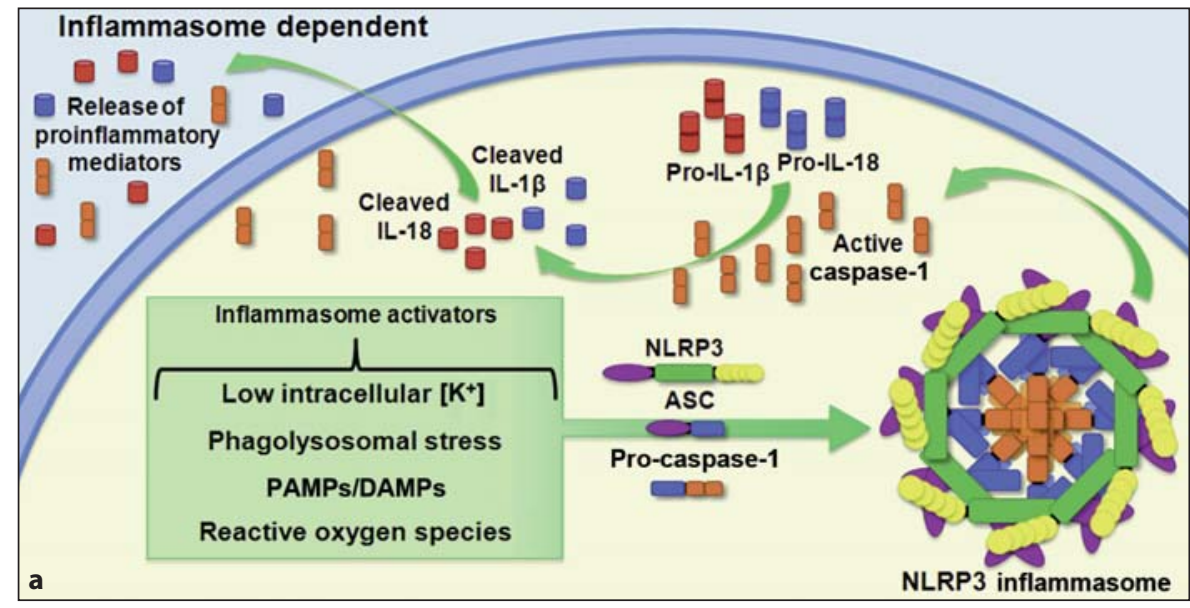

Inflammasome independent

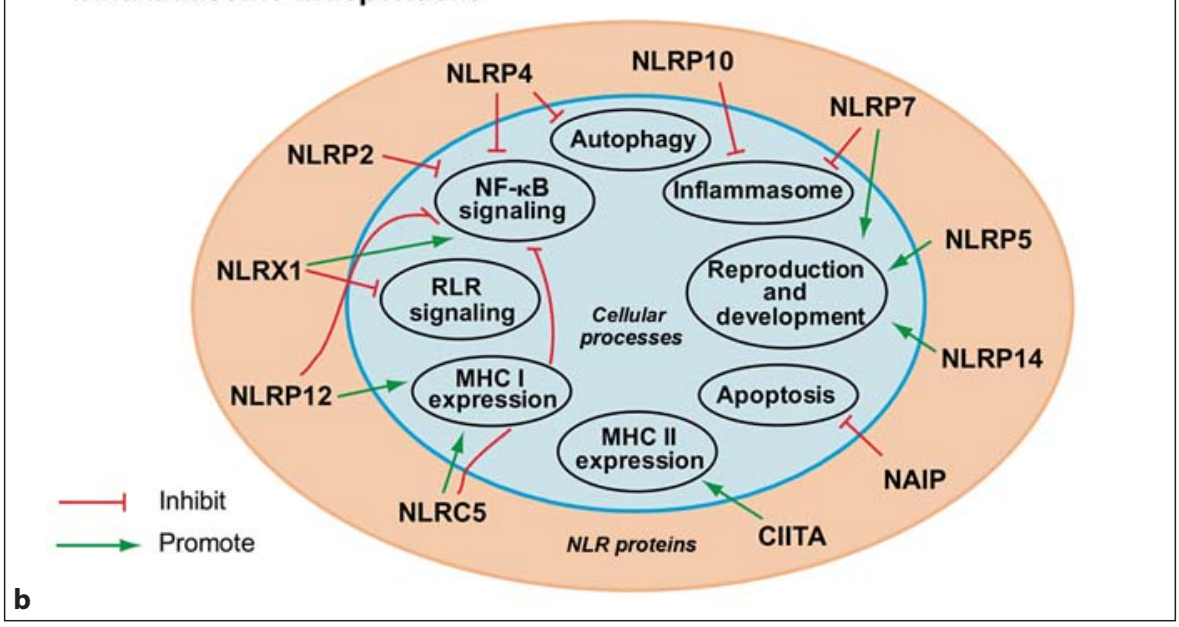

tion domains producing PYD-containing NLR (NLRP), NLRC, NLRB and NLRA subfamilies [1]. The second classification divides genes based on phylogenetic similarities to produce NOD, interleukin (IL)-1 $\beta$-converting enzyme protease-activating factor (IPAF) and NLRP subfamilies [2]. The NOD subfamily consists of membraneassociated NLRs that are predominantly characterized by their involvement in autophagy and induction of nuclear factor- $\kappa B$. There are many extensive reviews focused on the NOD subfamily, and thus, this article will not focus on the biology of these NLRs.

There are 14 identified human NLRPs, all of which contain PYD, NACHT and LRR domains with the exception of NLRP10, which lacks the LRR. In addition to the three conserved domains, NLRP1 contains FIIND (domain with function to find) and CARD domains which contribute to its function in inflammasome formation (see below) [3]. While some members of this subfamily are well understood, there are a number of NLRPs for which their function has yet to be fully determined (table 1) [2].

The IPAF subfamily consists of two members, IPAF (or NLRC4, i.e. CARD containing NLR4) and neuronal apoptosis inhibitory protein (NAIP, or NLRB1, i.e. BIR containing NLR1). NLRC4 is noted for its ability to form an inflammasome that responds primarily to bacteria with type III/IV secretion systems and PAMPs such as flagellin and type III secretion apparatus [2]. In contrast, NAIP is known for its antiapoptotic properties [4].

Both the NLRP and IPAF members have gained notoriety in recent years due to the ability of some members to form multiprotein inflammasome complexes capable of responding to both pathogen- and host-derived signals. These inflammasomes are primarily caspase-1-activating platforms that induce the maturation of pro-cytokines, most notably IL-1 $\beta$ and IL-18 (fig. 1). The most widely 
studied is the NLRP3 inflammasome, which consists of NLRP3, caspase-1 and the adaptor protein apoptosisassociated speck-like protein (ASC). Upon activation, NLRP3, ASC and caspase-1 oligomerize via homotypic interactions between respective PYD and CARD protein domains. The resulting high-molecular-weight complex forms a ring-like structure (the inflammasome) that triggers caspase- 1 autoprocessing into an active cysteine protease [2]. Among other functions, active caspase-1 cleaves members of the IL-1 superfamily from their inactive precursor forms to active secreted cytokines (fig. 1). The NLRP1 and NLRC4 inflammasomes contain structural differences to the NRLP3 inflammasome, but serve the common purpose of caspase-1 activation.

The increasing interest in the role of NLRs in the pathogenesis of non-microbial diseases stems from several observations. First, activating NLRP3 mutations are known to cause a variety of autoinflammatory disease in humans that comprise the cryopyrin-associated periodic syndromes (CAPS, see below) [5]. Second, as caspase-1activating platforms, the range of potential inflammasome effector molecules extends beyond IL- $1 \beta$ and IL-18 implicating NLRs in a variety of cellular functions that can impact disease. Caspase-1 regulates the release of proinflammatory secretory proteins that lack a signal peptide such as high-mobility group box 1 and fibroblast growth factor 2 [6-8]. Caspase-1 also participates in apoptosis and the processing of non-cytokine substrates such as PARP and the glycolytic enzymes glyceraldehyde3 -phosphate dehydrogenase and aldolase $[9,10]$. Thus, the absence of IL-1 $\beta$ or IL-18 does not necessarily exclude a role for inflammasome-forming NLRs in disease pathogenesis.

Third, the mechanisms leading to inflammasome assembly and activation, while not completely understood, provide a basis for NLR activation as a consequence of cellular stress and tissue injury. Several models examining NLRP3 inflammasome activation, for example, have been proposed to include a dependence on reactive oxygen species [11, 12], lysosomal destabilization [13] or the ATP-gated ion channel, P2X7 receptor [14, see ref. 2 for a detailed review of inflammasome structure and regulation]. Finally, while the formation and activity of inflammasomes are critical in a number of pathologies, there are a number of NLR-associated disorders that are independent of inflammasomes, suggesting a variety of functions for the NLRs. In this regard, NLRs (aside from NOD1/ NOD2) have been shown to regulate a wide range of cellular functions including nuclear factor- $\kappa \mathrm{B}$ signaling (NLRP2, NLRP4, NLRP12, NLRC5) [15-18], RIG-like re- ceptor signaling (NLRX1) [19], the inflammasome (NLRP7, NLRP10, NLCR5) [20-22], major histocompatibility complex gene regulation (CIITA, NLRP12, NLRC5) [23-25], autophagy (NLRP4) [26], reproduction and development (NLRP5, NLRP7 and NLRP14) [27-29] (fig. 1). Taken together, the existing data demonstrate a diverse assortment of potential NLR functions and mechanisms of activation that position this family of genes in the pathogenesis of many common non-microbial diseases (table 2).

\section{NLRs and the Pathogenesis of Non-Microbial Diseases}

\section{Cryopyrin-Associated Periodic Syndromes}

Familial cold autoinflammatory syndrome (FCAS), Muckle-Wells syndrome (MWS) and chronic infantile neurological cutaneous and articular syndrome belong to a class of autoinflammatory disorders referred to as CAPS [5]. Cryopyrin is another term for NLRP3, thus CAPS are strongly associated with this inflammasome. These disorders are caused by missense mutations, primarily in the NACHT-encoding region of the $n l r p 3 /$ ciasl gene, which lead to a gain of function phenotype that causes excessive production of IL-1 $\beta$ [30]. CAPS are characterized by diverse clinical manifestations including fever, urticarial rash and arthritis due in large part to neutrophil infiltration and inflammation. Central nervous system (CNS) manifestations occur in the more severe forms of CAPS and consist of chronic headaches, aseptic meningitis, ocular disease and perceptive deafness [5]. The progression and severity of CAPS is quite heterogeneous, and the three members of CAPS all share similar characteristics along a spectrum of severity, with the chronic infantile neurological cutaneous and articular syndrome being the most and FCAS the least severe. FCAS rarely has a neurological component but shares many symptoms with the other two disorders and also includes exacerbation in response to cold temperature [5].

In an effort to improve the understanding and treatment of CAPS, transgenic mouse models were generated through point mutations in the Nlrp3 gene resulting in recapitulation of the disease phenotype [31,32]. Knock-in mice carrying R258W (model MWS), L351P and A350V mutations (model MWS and FCAS, respectively) in the Nlrp3 gene displayed excessive inflammasome activation and Th17 responses resulting in increased inflammation in the CNS, synovium, skin and liver compared to wildtype (WT) mice. Bone marrow chimeric studies revealed 
that R258W mutation in the hematopoietic cell compartment, particularly antigen-presenting cells, primarily contributed to the disease phenotype that was effectively reversed by blocking IL-17A and the IL-1 receptor [32]. Similarly, CAPS-inducing Nlrp3 mutants L351P and A350V drove both innate (inflammasome/IL-1 $\beta$ ) and Tcell-dependent inflammation [31]. L351P and A350V Nlrp3 transgenic mice crossed onto a Rag1-/- background (unable to generate mature $\mathrm{T}$ or $\mathrm{B}$ cells) had improved survival, but the mice were only fully protected on an ASC-/- background, suggesting primarily innate (i.e. inflammasome-dependent) inflammation in this model [31]. These in vivo models have shed significant light onto the molecular events in the pathogenesis of CAPS and have opened the door to potential therapeutics.

\section{Joint Disorders}

The most common disorders associated with joint inflammation and pain is gout, osteoarthritis and rheumatoid arthritis (RA). Gout is characterized by pain and inflammation of the peripheral joints due to the deposition of monosodium urate (MSU) crystals. MSU has been characterized as a danger signal that is released from dying cells. In 2006, Martinon et al. [33] demonstrated that MSU and calcium pyrophosphate crystals were able to directly activate the NLRP3 inflammasome in human monocytes and murine macrophages assessed through caspase- 1 and IL-1 $\beta$ maturation. The effect of MSU-induced IL-1 $\beta$ activation was abrogated in mice or cells deficient in Nlrp3, ASC and caspase-1. Transgenic mice lacking the LRR domain of Nlrp3 display reduced inflammatory responses to MSU similar to Nlrp3-/- mice, indicating that the LRR domain is important in MSU sensing [34]. The efficacy of inflammasome inhibition in the amelioration of MSU-induced inflammation led to a pilot study showing the efficacy of anakinra (recombinant IL-1 receptor antagonist, IL-1Ra) in reducing inflammation and clinical symptoms in patients with gout [35].

RA is a chronic inflammatory disorder involving inflammation of the synovium, leading to degradation of the articular cartilage and stiffening of the joints. While RA most commonly affects the synovium, it is considered a systemic disorder that can manifest in other areas of the body such as the lungs and vasculature. Polymorphisms in NLRP3 link significantly to RA [36], and NLRP1 and NLRP3 gene expression is elevated in peripheral blood mononuclear cells of RA patients [37]. Consistent with these observations, increased expression of NLRP 3 and ASC is seen in the synovium of RA patients, including the
Table 2. NLRs and associated non-microbial diseases

\begin{tabular}{|c|c|}
\hline $\mathrm{NLR}^{1}$ & Associated diseases \\
\hline NLRP1 & $\begin{array}{l}\text { neuronal injury } \\
\text { systemic sclerosis } \\
\text { vitiligo }\end{array}$ \\
\hline NLRP3 & $\begin{array}{l}\text { gout } \\
\text { RA } \\
\text { AD } \\
\text { CAPS } \\
\text { MS } \\
\text { cardiovascular disease } \\
\text { chronic obstructive pulmonary disorders } \\
\text { allergic asthma } \\
\text { inhaled particulate } \\
\text { sterile liver injury } \\
\text { I/R } \\
\text { obesity/insulin resistance } \\
\text { CKD } \\
\text { inflammatory bowel disease } \\
\text { contact hypersensitivity }\end{array}$ \\
\hline NLRP5 & neuronal injury \\
\hline NLRP6 & inflammatory bowel disease \\
\hline NLRP7 & hydatidiform moles \\
\hline NLRP14 & spermatogenic failure \\
\hline NAIP & spinal muscular atrophy \\
\hline CIITA & bare lymphocyte syndrome \\
\hline
\end{tabular}

CIITA = Class II, major histocompatibility complex transactivator.

${ }^{1}$ Disease association may be human or mouse homolog in experimental mouse model.

endothelium and infiltrating leukocytes [38]. Expression of numerous NLRPs such as NLRP1, NLRP3, NLRP6, NLRP10, NLRP12, NLRP14 and other inflammasome components including ASC, pro-IL-1 $\beta$ and caspase- 1 has also been detected in fibroblast-like synoviocytes [39]. Interestingly, NLRP expression was also detected in the synovium of osteoarthritis patients, in a manner that was generally indistinguishable from RA [39]. Anakinra is effective in the treatment of RA, suggesting that inflammasome activation and secretion of IL- $1 \beta$ are key processes involved in RA and associated disease pathogenesis [40].

\section{Brain, CNS and Neuronal Disorders}

Work published on inflammation in the CNS and specific CNS-related disorders has primarily investigated the roles of IL-1 $\beta$, IL-18 and caspase-1. Human and animal models of diseases such as Huntington's and Parkinson's disease as well as amyotrophic lateral sclerosis have 
all demonstrated involvement of these proinflammatory mediators, but have yet to demonstrate a direct association with any particular NLR protein [41-43]. However, NLRs may play a role in degenerative neurological disorders. NLRP1 and NLRP5 have been directly implicated in neuronal death following serum starvation in vitro and cerebral artery occlusion in vivo [44]. Similarly, NLRs have been shown to contribute to Alzheimer's disease (AD), a form of dementia characterized by progressive loss of neurons and synapses coinciding with the accumulation of amyloid- $\beta$ plaques and neurofibrillary tangles, which are aggregates of hyperphosphorylated $\tau$ protein. Fibrillar amyloid- $\beta$ induces phagosomal damage in microglia resulting in proinflammatory chemokine and cytokine secretion, including IL-1 $\beta$ release [45]. Nlrp3-/- and ASC-/- microglia demonstrated a significant reduction in the proinflammatory mediators when treated with amyloid- $\beta$, suggesting that the NLRP3 inflammasome plays an important role in this context [45]. A screen of $\mathrm{AD}$ patients also revealed elevated levels of caspase-1, which may be associated with NLR inflammasome activity [46]. Taken together, these results suggest a role for NLR proteins in the pathogenesis of AD and possibly other neurodegenerative diseases.

Multiple sclerosis (MS) is an autoimmune disorder characterized by chronic inflammation and demyelination of the neurons of the CNS. Increased levels of caspase- 1 have been observed in MS patients, in cell culture studies and in the mouse model of MS, i.e. experimental autoimmune encephalomyelitis (EAE) $[47,48]$. In MS patients, increased levels of caspase-1 and IL-18, but not IL$1 \beta$, were detected in peripheral blood monocytes [48]. Consistent with these findings, ASC and Nlrp3 were found to play a role in the progression of disease in the EAE model $[49,50]$. The study by Gris and colleagues [49] demonstrates the requirement for NLRP3 in the expression of interferon (IFN)- $\gamma$ and IL-17, which drive Th1 and Th17 immune responses and the neurological injury in this model. Nlrp3-/- mice demonstrated reduced inflammation, injury and clinical manifestations of the disease corresponding with a reduction in IFN- $\gamma$ and IL-17secreting CD4+ T cells. IL-18 was the critical effector downstream of NLRP3, since IL-18 and Nlrp3-deficient mice exhibited similar phenotypes [49]. In contrast, another group reported a predominant role for ASC and caspase-1 but not for NLRP3 in EAE progression [50]. ASC-/- but not Nlrp3-/- mice displayed a reduction in clinical score as well as in IFN- $\gamma$ and IL-17-secreting $\mathrm{CD} 4+\mathrm{T}$ cells obtained from the draining lymph nodes and the spinal cord. Together, the existing data strongly suggest a role for the inflammasome in the pathogenesis of MS; however, the discrepancy observed in recent studies regarding the pertinent genes may relate to the sensitivity of the EAE model to environmental conditions.

Spinal muscular atrophy is characterized by a loss of motor neurons in the spinal cord and is attributed primarily to a deficiency in functioning survival motor neuron (SMN1 and SMN2) genes. Early reports indicated a deficiency in the antiapoptotic protein NAIP among specific populations with the disorder [51]. More recently, several groups have suggested that the number of SMN2 gene copies and deletion of exon 5 in the NAIP gene are factors that affect disease severity and progression [52]. NAIP is also reported to be downregulated in $\mathrm{AD}$ patients and to play a protective role in an animal model of Parkinson's disease $[53,54]$. The exact role of NAIP in the pathogenesis of spinal muscular atrophy and other neurodegenerative diseases is not clear but may be related to its role in apoptosis. NAIP is unique among the NLRs in that it does not appear to play a major role in inflammation, but acts to suppress apoptosis through various pathways, including inhibiting the cleavage of apoptotic caspases 3 and 9. In this regard, the BIR domain in addition to the NACHT domain is essential for its antiapoptotic function through direct interactions with caspase-3 and apoptosome-forming proteins, Apaf- 1 and procaspase- $9[4,55]$.

\section{Cardiovascular Diseases}

Research over the past decade indicates that inflammation is a key mediator in the development of cardiovascular diseases. Recent genome-wide association studies found that polymorphisms in the NLRP3 locus were concordant with fibrinogen gene variants that are associated with increased circulating fibrinogen levels, a risk factor for cardiovascular disease [56]. Consistent with these observations, inflammasome involvement has been demonstrated in the context of cardiac ischemia-reperfusion (I/R) injury [57]. Kawaguchi et al. [57] demonstrated increased ASC expression in the hearts of patients following myocardial infarction and less cardiac injury following I/R injury in ASC-/- and caspase-1-/- mice. Compared to WT mice, ASC-/- and caspase-1-/- mice had better left ventricular function and less inflammation following ischemia. Interestingly, inflammasome activation occurred not only in infiltrating leukocytes but also in cardiac fibroblasts, likely triggered by reactive oxygen species and $\mathrm{K}^{+}$efflux. ASC has also been shown to play a role in a vascular injury/restenosis model in mice [58]. Increased ASC expression in macrophages and vascular smooth muscle cells were observed at the site of wire-in- 
duced vascular injury and coincided with neointimal formation [58]. Neointimal formation and restenosis was reduced in ASC-/- mice and corresponded, not surprisingly, with less IL-1 $\beta$ and IL-18 expression. Unlike the findings in the myocardium, ASC-dependent restenosis following vascular injury was entirely dependent on infiltrating leukocytes.

The deposition of cholesterol on arterial walls and subsequent uptake by circulating monocytes precedes differentiation of monocytes into foam cells. Foam cells are key mediators in the development of atherosclerotic lesions and it is believed that inflammation is driven by the conversion of cholesterol into a crystalline form within these macrophages [59]. Studies have shown that cholesterol crystals activate the NLRP3 inflammasome in macrophages [60]. In the absence of NLRP3, ASC or caspase-1, IL-1 $\beta$ maturation is abolished in response to cholesterol crystals, an effect that was also lost in cathepsin-B- and cathepsin-L-deficient cells providing evidence for the lysosomal disruption/cathepsin activation model of the inflammasome. In vivo, low-density lipoprotein receptordeficient mice that received Nlrp3-/- or ASC-/- bone marrow experienced a reduced burden of atherosclerotic lesions, providing strong support for a role of the inflammasome in the pathogenesis of vascular disease. In an interesting twist, Freigang et al. [61] outlined the role of NF-E2-related 2 (Nrf2), an oxidative stress responsive transcription factor in the cholesterol crystal model. Apolipoprotein E (ApoE)-/- mice have been shown to have an increased susceptibility for the development of atherosclerosis. Using an ApoE-/- background, Nrf2-/ApoE-/- mice were protected from IL-1-dependent atherosclerotic damage while $\mathrm{Nrf2}+/-$ ApoE-/- mice were not [61]. Cholesterol crystal-induced IL-1 $\beta$ production was not only significantly reduced in caspase-1-/- and Nlrp3-/- macrophages, but also in Nrf2-/- cells, indicating a dependency on both the NLRP3 inflammasome and Nrf2, reinforcing the link between inflammasome activation and the upregulation of antioxidant genes $[62,63]$. Finally, NLRs and the inflammasome are also indirectly linked to cardiovascular disease, given their roles in obesity and insulin resistance that are important cardiovascular risk factors (see below for further details). Taken together, these studies show a significant role for the NLRP3 inflammasome in cardiovascular disease and in disease states associated with increased cardiovascular risk.

\section{Pulmonary Diseases}

NLRs are known to be involved in the host response and control of pulmonary infections that involve diverse pathogens such as viruses, bacteria and mycobacteria [64]. The role of NLRs in airway diseases associated with autoinflammation and environmental antigens is less well defined than in microbial infections, but still substantial. Screening a cohort of patients with systemic sclerosis-related fibrosing alveolitis demonstrated the presence of NLRP1 single nucleotide polymorphisms (SNPs) as a significant risk factor within patient populations measured against healthy controls, suggesting that NLRs play a role in non-microbial driven inflammation and lung disease [65].

Chronic obstructive pulmonary disease is commonly broken down into two categories: chronic bronchitis and emphysema. Chronic bronchitis is characterized by inflammation and damage to the upper airways, while emphysema is characterized by inflammation and damage to the alveoli. The inflammasome has been show to play a role in mouse models of lung injury and emphysema. Nasal installation of elastase in mice results in the degradation of extracellular matrix and the alveolar wall to produce an emphysema-like state. Increased production of proinflammatory cytokines, such as tumor necrosis factor- $\alpha$, IL- 6 and IL-1 $\beta$, and increased neutrophil infiltration are associated with elastase administration in WT mice [66]. IL-1Ra administered to mice prior to elastase exhibited less inflammation and tissue damage. In addition, when elastase was administered to ASC-/-, IL1R-/- and MyD88 -/- mice, the markers of inflammation and injury were significantly less, indicating significant involvement of the inflammasome and the IL-1 signaling axis in the pathogenesis of disease. Furthermore, the efficacy of uricase in reducing elastase-mediated injury suggested that the underlying mechanism may involve uric acid-induced activation of the NLRP3 inflammasome [66]. Similarly, using bleomycin to induce acute injury, chronic inflammation and lung fibrosis, the IL-1 signaling axis was shown to contribute significantly to this disease model [67]. IL-1R-/- or MyD88 -/- mice were resistant to bleomycin-induced injury, and pretreatment with IL-1Ra also protected the lungs from extensive inflammation and fibrosis. Bleomycin-induced inflammation and tissue damage was also substantially decreased in ASC-/- mice, and a subsequent study confirmed the involvement of NLRP3 and caspase-1 $[67,68]$. It was hypothesized that the underlying pathogenesis of bleomycin-induced injury involved uric acid release and inflammasome activation. Indeed, exogenous uric acid induced lung inflammation and reducing uric acid with the xanthine oxidase inhibitor allopurinol or uricase decreased bleomycin-induced inflammation and injury [68]. 
The role of NLRP3 and the inflammasome in asthma is controversial. Kool et al. [69] demonstrated that release of uric acid upon allergen exposure leads to the development of a Th2-mediated response that is independent of the NLRP3 inflammasome. Using ovalbumin (OVA) + alum and house dust mite-allergic lung inflammation models, an increase in uric acid was observed that coincided with eosinophil and lymphocyte accumulation in the lung and the development of a Th2 immune response. The response was attenuated when allergens were coadministered with uricase, suggesting that uric acid was essential to the response. Increased uric acid was also seen in bronchoalveolar lavage fluid of asthma patients. Despite the clear adjuvant effect provided by uric acid in these models, administration of OVA + alum or house dust mite to Nlrp3-/-, ASC-/- or IL-1R-/- mice did not reduce eosinophil or lymphocyte recruitment, suggesting that the NLRP3 inflammasome or IL-1 signaling was not directing the development of the Th2 response. Rather, phosphoinositide-OH-3 kinase and Syk were needed for uric acid-mediated adjuvanticity [69]. These findings directly contradict another study using the OVA asthma model demonstrating a substantial reduction in inflammation and leukocyte recruitment to the lung in Nlrp3-/- and IL-1R-/- mice compared to WT mice [70]. Inflammasome and IL-1-deficient mice displayed significantly lower Th2-associated cytokines, IL-13-secreting CD4+ T cells and dendritic cells in the draining lymph nodes following OVA challenge. While controversial at the moment, further research may clarify the roles of NLRs and inflammasomes in the development of Th2 immune responses and allergic lung diseases.

Severe chronic lung diseases can result from the pulmonary exposure to particulates such as silica and asbestos (asbestosis, silicosis). Caspase- 1 and IL- $1 \beta$ maturation were activated by silica and asbestos in THP-1 cells and WT murine macrophages in an NLRP3 and ASC-dependent manner [71]. Blocking reactive oxygen species or phagocytosis by treatment with cytochalasin $\mathrm{D}$ prior to exposure to particulates prevented inflammasome activity, indicating that endocytosis of the particles was required for activation. These results were recapitulated in vivo by Cassel et al. [72], demonstrating the importance of the NLRP3 inflammasome in response to pulmonary exposure to asbestos and silica. In a similar vein, the NLRP3 inflammasome and IL-1 $\alpha$ have been implicated in the pulmonary response to nanoparticles silica dioxide $\left(\mathrm{SiO}_{2}\right)$ and titanium dioxide $\left(\mathrm{TiO}_{2}\right)$ that are commonly used in product manufacturing [73]. IL-1 $\beta$ maturation and caspase-1 activation occurred in THP-1 cells and murine macrophages stimulated with $\mathrm{TiO}_{2}$ and $\mathrm{SiO}_{2}$, a response abrogated in Nlrp3 -/- and ASC-/- macrophages. In contrast to the effect of other particulate matter, such as MSU, the activation of the inflammasome by nanoparticles did not require cytochalasin-D-dependent cytoskeletal rearrangement. In vivo, pulmonary exposure to $\mathrm{TiO}_{2}$ resulted in inflammasome activation and neutrophil recruitment in WT mice. Nlrp3-/-, ASC-/and caspase-1-/- mice demonstrated attenuated inflammatory responses, indicating that the NLRP3 inflammasome was only partially mediating the inflammation following nanoparticle exposure. In this regard, IL- $1 \alpha$ and signaling via the IL-1R was crucial [73].

\section{Liver Diseases}

An interest in researching the role of NLRs in sterile injury to the liver has emerged due to the realization that NLRs respond strongly to host-derived, endogenous antigens. McDonald et al. [74] used a focal hepatic burn model to assess the impact of the NLRP3 inflammasome on neutrophil recruitment. Nlrp3-/- and ASC-/- mice exhibited decreased levels of IL-1 $\beta$ which was essential to trigger the cascade of leukocyte recruitment to the site of injury. As mentioned in the introduction, evidence suggests that ATP binding to the P2X7 receptor and subsequent $\mathrm{K}^{+}$efflux stimulates activation of the inflammasome. Consistent with this model, decreasing the level of extracellular ATP using apyrase or pharmacological inhibition of the P2X7 receptor resulted in impaired neutrophil recruitment. Likewise, neutrophil adherence was decreased and IL-1 $\beta$ release was abrogated in P2X7-/mice [74].

The NLRP3 inflammasome may also play a role in toxin-induced hepatic injury. Acetaminophen (AAP) overdose results in an accumulation of toxic metabolites that deplete the liver of the antioxidant glutathione causing damage and potentially failure of the liver. Nlrp3-/-, ASC-/- and caspase-1-/- mice showed increased survival rates and decreased liver damage in histological analysis using a model of AAP-mediated hepatotoxicity [75]. Survival rates were the same for WT as for IPAF-/- mice, suggesting that the injury is driven specifically through the NLRP3 inflammasome. In addition, TLR9 was needed to induce transcription and production of pro-IL- $1 \beta$ and pro-IL-18, an effect that was reduced by aspirin. Subsequently, TLR9 deficiency or coadministration of aspirin reduced AAP-induced liver injury. These findings were followed up by another group that applied the same methodology but were unable to demonstrate a reduction in AAP-mediated injury in mice lacking the various com- 
ponents of the NLRP3 inflammasome and IL-1 signaling [76]. The contradictory findings leave the subject open to debate as to the involvement of the NLRP3 inflammasome in AAP-mediated hepatotoxicity. Finally, inflammasome involvement also contributes to hepatic stellate cell activation and experimental liver fibrosis induced by carbon tetrachloride and thioacetamide. MSU upregulated transforming growth factor- $\beta$ and collagen- 1 expression in isolated WT hepatic stellate cells but not in ASC-/- hepatic stellate cells. Consequently, intraperitoneal administration of carbon tetrachloride increased the expression of transforming growth factor- $\beta$ and collagen-1 and subsequent liver fibrosis in mice that was reduced in Nlrp3-/- and ASC-/- animals [77]. Similar findings were seen in ASC-/- mice receiving thioacetamide. In summary, substantial evidence exists that the inflammasome plays a role in liver injury.

\section{Metabolic Disorders}

Recent studies suggest an important role for mitochondrial stress in driving inflammation and inflammasome activation, which may indicate a role for NLRs in a number of different metabolic disorders [12]. Zhou et al. [11] first demonstrated a role for NLRP3 in glucose metabolism. Thioredoxin-interacting protein (TXNIP), a negative regulator of the antioxidant enzyme thioredoxin, was found to regulate NLRP3 activation during oxidative stress. TXNIP plays a significant role in glucose metabolism, with its expression increased by hyperglycemia and decreased by insulin. In pancreatic islet cells, hyperglycemia triggered a small, albeit significant, amount of IL-1 $\beta$ secretion, a response that was absent in Nlrp3-/- or TXNIP-/- cells. Subsequent in vivo studies confirmed that Nlrp3-/- and TXNIP-/- mice display a similar improvement in glucose tolerance and insulin sensitivity compared to WT mice fed a high fat diet [11]. Masters et al. [78] also examined the role of the Nlrp3 inflammasome in experimental diabetes. Islet amyloid polypeptide (IAPP), a protein implicated in the pathogenesis of type 2 diabetes mellitus, was found to activate the Nlrp3 inflammasome in macrophages via the phagolysosome. IAPP transgenic mice also displayed an increase in IL-1 $\beta$ expression in pancreatic islets, suggesting that IAPP may contribute to diabetes pathogenesis via the inflammasome. In contrast to previous studies, TXNIP was not required for Nlrp3 inflammasome activation in macrophages. While the proposed mechanisms may differ, these studies highlight the potential role for the inflammasome in obesity-related diseases such as diabetes.
More recently, several studies have emerged that confirm a role for the NLRP3 inflammasome in obesity, adipocyte biology and insulin sensitivity. Stienstra et al. [79] demonstrated that caspase-1-dependent production of IL-1 $\beta$ had a significant negative impact on adipogenesis, insulin resistance and obesity in general, strengthening the inflammation-related link to disease pathogenesis. Caspase-1-/- cells or antagonism of IL- $1 \beta$ significantly improved the adipocyte phenotype and insulin sensitivity. In obesity models in vivo, both caspase- 1 and IL-1 $\beta$ were found to be increased in adipose tissues, and caspase-1 deficiency or inhibition substantially improved insulin sensitivity, adipose tissue morphology and composition, fat oxidation rates, bone mass and glucose tolerance. Similar observations were also seen in Nlrp3-/- fat cells and mice but not as pronounced as in caspase- 1 deficiency [79]. Vandanmagsar et al. [80] also noted increased NLRP3 and IL-1 $\beta$ expression in adipose tissue that correlated with the degree of obesity and insulin resistance. Ceramide generated from fatty acids was found to be an NLRP3 trigger, and Nlrp3-/- mice had improvements in insulin sensitivity, hepatic steatosis and an alteration in adipose tissue macrophages towards an M2 phenotype. In addition, significant changes were also noted in T-cell populations in various fat compartments with a significant alteration in the numbers or phenotype of CD4+ and CD8+ lymphocytes. NLRP3 inflammasome activity associated with obesity may be driven by the presence of saturated fatty acids such as palmitate [81]. Palmitate, which is increased in high fat diets, activated the NLRP3 inflammasome via reactive oxygen species production, reduced autophagy mediated by downregulation of the antioxidant enzyme AMP-activated protein kinase. Similarly, in MSU-induced gouty arthritis, fatty acids can act on the TLR 2 to increase IL- $1 \beta$ in an ASC- and caspase-1-dependent fashion [82]. Csak et al. [83] found that saturated fatty acids induce inflammasome activation which in concert with endotoxin exposure may be the underlying mechanism involved in the development of nonalcoholic steatohepatitis. Together, these studies confirm important roles for the inflammasome in metabolic disorders, including insulin signaling. The inflammasome may represent a key pathway that links diet and obesity to inflammation, type 2 diabetes and organ dysfunction.

\section{Kidney Diseases}

Despite a large number of diseases associated with inflammation of the kidney and altered function, there are very few publications on the topic of NLR expression 
and activity in the kidney. Chronic kidney disease (CKD) is a progressive loss of renal function that occurs over an extended period of time. The most common causes of CKD are diabetes mellitus, glomerulonephritis and hypertension. Options for treatment are lacking and the focus lies on slowing the progression of the disease. Several lines of investigation have suggested a role for the inflammasome in CKD. P2X7-/- mice experienced less tubular injury, inflammation and renal fibrosis compared to WT mice with renal injury induced by unilateral ureteric obstruction (UUO) [84]. Similarly, biglycan and hyaluronan, two endogenous danger signals that activate NLRP3, also play a role in renal injury $[85,86]$. The direct role of NLRP3 was subsequently established in human CKD and in mice [87]. Expression of NLRP3, IL-1 $\beta$, IL-18 and caspase-1 activation increased over the time course of UUO in mice confirming inflammasome activity in this model. Compared to WT mice, kidneys from Nlrp3-/- animals displayed less tubular damage, interstitial fibrosis and inflammatory cell infiltrates. Interestingly, studies using bone marrow chimeric mice revealed a function for NLRP3 in both the renal and hematopoietic compartments. In human CKD, NLRP3 gene expression was increased in a variety of non-diabetic kidney diseases and correlated with kidney function [87].

The inflammasome has also been shown to play a role in I/R injury in the kidney. Caspase- 1 was shown to play a significant role in $\mathrm{I} / \mathrm{R}$ injury in the kidney mainly through its effects on IL-18 maturation [88]. Mice deficient in caspase-1 experienced less renal failure, neutrophil recruitment and pathological tubular injury compared to WT mice. Iyer et al. [89] first showed reduced tubular injury following I/R of the kidney in Nlrp3-/-, ASC-/- and caspase-1-/- mice. Inflammasome activation in macrophages was triggered by the release of mitochondrial ATP from necrotic cells acting via P2X7, in addition to priming by endogenous DAMPs, such as hyaluronic acid and biglycan. Shigeoka et al. [90] reported similar findings regarding the role of NLRP3 in renal I/R. Kidney function and tubular injury was preserved in Nlrp3-/- mice compared to WT counterparts. Interestingly and in contrast to prior studies $[88,89]$, although Nlrp3-/- mice exhibited a reduction in the production of mature IL-1 $\beta$ and IL-18, mice deficient in IL-18, IL-1R, ASC and caspase-1 were not protected from I/R injury and exhibited a similar phenotype as WT controls [90]. These observations, in addition to bone marrow chimeric studies, suggested that $\mathrm{I} / \mathrm{R}$ injury in the kidney was mediated by inflammasome-independent NLRP3 func- tion in the epithelial cell compartment. While no mechanism was proposed, the results were consistent with a role for epithelial NLRP3 in the UUO model of renal injury [87].

\section{Gastrointestinal Disorders}

The gastrointestinal tract is a unique area of the body in terms of immunological responses and tolerance to non-self antigens. The constant presence of dietary antigens and commensal microbiota necessitates the presence of a fortified mucosal barrier for the intestinal epithelial cells. Beneath the single epithelial layer lies a network of leukocytes, including macrophages, $\mathrm{T}$ and $\mathrm{B}$ cells ready to respond to any disruptions to intestinal homeostasis assessed by the presence of PAMPs and DAMPs. The responses of the NLRP3 and IPAF inflammasomes are well characterized for enteric organisms [64]. Thus, it is not surprising that the NLRs play a major role in inflammatory bowel disease (IBD) that includes Crohn's disease (CD) and ulcerative colitis. Both are characterized by chronic intestinal inflammation, abdominal pain, rectal bleeding and diarrhea. While CD can affect all regions of the gastrointestinal tract (most commonly involving the terminal ileum and colon), ulcerative colitis is generally restricted to the colon and rectum.

Differential expression of several NLRPs was observed in Paneth cells from IBD patients [91]. NLRP1 and NLRP7 gene expression was upregulated, while NLRP8 and NLRP11 expression was significantly downregulated in IBD patients. The roles of NLRP7, NLRP 8 and NLRP11 are not well defined in the literature and it will be interesting to see if and how they play a role in the regulation of IBD. In most organ systems, the functioning NLRP3 inflammasome appears to play a role in the etiology and exacerbation of inflammatory disorders. However, SNP array studies have outlined the significance of NLRP3 polymorphisms in $\mathrm{CD}$, indicating a hypofunctional NLRP3 allele associated with increased susceptibility to CD [92]. Mouse models of IBD have generally confirmed a protective role for NLRP3 in the dextran sulfate sodium (DSS) and 2,4,6-trinitrobenzenesulfonic acid-induced models of colitis. Using these models, several studies have demonstrated that Nlrp3-/-, ASC-/- and caspase-1-/mice were much more susceptible to epithelial barrier damage, suggesting a role for the NLRP3 inflammasome in the maintenance of intestinal homeostasis [93-96]. Inflammasome-deficient mice exhibited increased inflammation, tissue damage and decreased survival. In addition, Hirota et al. [95] observed a significant difference in the microbiota between Nlrp3-/- and WT mice and 
speculate that it may be reflective of the inability of the Nlrp3-/- mouse to properly maintain intestinal homeostasis. Together, these studies support the notion that the NLRP3 inflammasome plays a key role in intestinal inflammation and in damage induced through experimental models of colitis.

In addition to the NLRP3 inflammasome, recent evidence suggests that the NLRP6 inflammasome is also a key regulator of intestinal homeostasis. Similar to the findings with NLRP3, mice deficient in Nlrp6 are more susceptible to DSS-induced colitis that coincides with a significantly altered gut microbiota (dysbiosis) [97]. The co-housing and cross-fostering of ASC-/-, caspase-1-/and Nlrp6-/- mice with WT mice revealed that the increased susceptibility to DSS-induced injury could be transferred to WT mice and is thought to be driven by dysbiosis [97]. Chimeric studies indicated that the expression of NLRP6 in non-hematopoietic cells, particularly the epithelium, is essential for the maintenance of normal microbiota [97] while expression in hematopoietic cells may function to negatively regulate tumorigenesis [98].

\section{Skin Disorders}

Similarly to the gut, the skin serves as a barrier to prevent access of potential pathogens and environmental hazards. The defenses of the skin include commensal bacteria, antimicrobial peptides and a system of leukocytes beneath the skin that serve to protect the host. Research into the role of NLR proteins in protection of the skin and mediation of inflammatory disorders is beginning to emerge. Vitiligo is an autoimmune disorder characterized by a loss of skin pigmentation due to the destruction of melanocytes. Several studies have been published correlating NLRP1 and NLRP3 SNPs with the disorder [99, 100]. Polymorphisms in NLRP1, NLRP3 and NLRP12 have also been associated with atopic dermatitis [101]. Consistent with these data, the inflammasome has been demonstrated in the pathogenesis of contact hypersensitivity (CHS), a T-cell-mediated form of delayed-type hypersensitivity in the skin in response to allergens. CHS is mediated in part by the NLRP3 inflammasome as demonstrated through the use of a chemically induced hypersensitivity model $[102,103]$. Primary keratinocytes and keratinocyte-derived cells express many different NLRPs and are capable of forming functional inflammasomes. Stimulation with contact sensitizers such as trinitrochlorobenzene and dinitro-1fluorobenzene was sufficient to induce inflammasome activation and IL-1 $\beta$ maturation in an ASC- and caspase- dependent manner. Edema and vasodilation characteristics of CHS were attenuated in Nlrp3-/-, ASC-/- and IL1R-/- mice following topical application of trinitrochlorobenzene or dinitro-1-fluorobenzene [103]. Nlrp3-/-and ASC-/- mice were also resistant to trinitrophenylchloride-induced CHS, an effect that likely occurs in the early sensitization step [102]. NLRP12 is also associated with CHS. The use of Nlrp12-/- mice did not affect levels of IL-1 $\beta$ in a CHS model, but the lack of NLRP12 appeared to disrupt proper migration of dendritic cells and neutrophils following topical application of oxazolone [104]. The disruption in leukocyte recruitment was not associated with a decreased expression of the CCR7 or CXCR4 chemokines, as Nlrp12--/- mice exhibited levels similar to WT mice. This novel study on the function of NLRP12 reminds us that the NLR proteins likely perform many important, inflammasome-independent functions that are yet to be defined.

\section{Future Perspectives}

The identification of NLRs in disease has increased substantially over the past 10 years. However, it is clear that much more work is required to elucidate their exact biology, mechanism of activation and, in the case of inflammasomes, their complete effector functions. While most work with the NLR family of proteins has focused on their role in driving inflammation through inflammasome formation (and IL-1 $\beta$ and IL-18 in particular), there is evidence to suggest that some NLRs (aside from NOD1 and NOD2) function independently of inflammasome formation and may even act in an anti-inflammatory capacity. The disease mechanisms related to inflammasome-independent NLR function remains to be determined. Similarly, even when the multiprotein complex of the inflammasome is formed, evidence of the numerous substrates of caspase-1 suggests that the inflammasome complex may have functions well beyond the activation of members of the IL-1 family. These data reveal that NLRs likely cannot be grouped together based on function, but rather exhibit diverse functions to regulate the consequences of microbial and non-microbial injury.

Finally, while a significant amount of data has now linked the NLRs and the inflammasomes to a variety of common diseases, the translation to therapeutics is required. The identification of the NLRPs and the inflammasomes has resulted in the successful application of anti-IL-1 $\beta$ therapies, such as IL-1Ra, which have proven to 
be effective in reducing symptoms in a number of autoinflammatory diseases, such as CAPS, gout and RA, and are being explored as a treatment for a wide variety of other disorders [5]. However, the effector functions of the NLRs and the inflammasome are diverse. Thus, specific inhibitors of NLRs and their associated proteins and effectors are needed to realize the full therapeutic benefit of the recent focus on this family of genes over the past decade. Continued interest in researching NLRs will undoubtedly broaden our understanding of their functions and how they may be manipulated in the treatment of a myriad of disorders.

\section{Acknowledgements}

P.L.B and D.A.M. are supported by salary awards and operating grants from Alberta Innovates Health Solutions and the Canadian Institutes for Health Research. D.A.M. holds a Tier 2 Canada Research Chair.

\section{References}

-1 Ting JP, Lovering RC, Alnemri ES, Bertin J, Boss JM, Davis BK, Flavell RA, Girardin SE, Godzik A, Harton JA, Hoffman HM, Hugot JP, Inohara N, Mackenzie A, Maltais LJ, Nunez G, Ogura Y, Otten LA, Philpott D, Reed JC, Reith W, Schreiber S, Steimle V, Ward PA: The NLR gene family: a standard nomenclature. Immunity 2008;28:285-287.

2 Schroder K, Tschopp J: The inflammasomes. Cell 2010;140:821-832.

3 Martinon F, Burns K, Tschopp J: The inflammasome: a molecular platform triggering activation of inflammatory caspases and processing of proIL-beta. Mol Cell 2002;10:417426.

-4 Davoodi J, Ghahremani MH, Es-Haghi A, Mohammad-Gholi A, Mackenzie A: Neuronal apoptosis inhibitory protein, NAIP, is an inhibitor of procaspase-9. Int J Biochem Cell Biol 2010;42:958-964.

5 Neven B, Prieur AM, Quartier dit Maire P: Cryopyrinopathies: update on pathogenesis and treatment. Nat Clin Pract Rheumatol 2008;4:481-489.

6 Keller M, Ruegg A, Werner S, Beer HD: Active caspase- 1 is a regulator of unconventional protein secretion. Cell 2008;132:818-831.

7 Lamkanfi M, Sarkar A, Vande Walle L, Vitari AC, Amer AO, Wewers MD, Tracey KJ, Kanneganti TD, Dixit VM: Inflammasomedependent release of the alarmin HMGB1 in endotoxemia. J Immunol 2010;185:43854392.

${ }_{8}$ Willingham SB, Allen IC, Bergstralh DT, Brickey WJ, Huang MT, Taxman DJ, Duncan JA, Ting JP: NLRP3 (NALP3, cryopyrin) facilitates in vivo caspase-1 activation, necrosis, and HMGB1 release via inflammasome-dependent and -independent pathways. J Immunol 2009; 183:2008-2015.

-9 Shao W, Yeretssian G, Doiron K, Hussain $\mathrm{SN}$, Saleh M: The caspase-1 digestome identifies the glycolysis pathway as a target during infection and septic shock. J Biol Chem 2007;282:36321-36329.
0 Zhou X, Gordon SA, Kim YM, Hoffman RA, Chen Y, Zhang XR, Simmons RL, Ford HR: Nitric oxide induces thymocyte apoptosis via a caspase-1-dependent mechanism. J Immunol 2000;165:1252-1258.

11 Zhou R, Tardivel A, Thorens B, Choi I, Tschopp J: Thioredoxin-interacting protein links oxidative stress to inflammasome activation. Nat Immunol 2010;11:136-140.

12 Zhou R, Yazdi AS, Menu P, Tschopp J: A role for mitochondria in NLRP3 inflammasome activation. Nature 2011;469:221-225.

13 Hornung V, Bauernfeind F, Halle A, Samstad EO, Kono H, Rock KL, Fitzgerald KA, Latz E: Silica crystals and aluminum salts activate the NALP3 inflammasome through phagosomal destabilization. Nat Immunol 2008;9: 847-856.

14 Kanneganti TD, Lamkanfi M, Kim YG, Chen G, Park JH, Franchi L, Vandenabeele P, Nunez G: Pannexin-1-mediated recognition of bacterial molecules activates the cryopyrin inflammasome independent of Toll-like receptor signaling. Immunity 2007;26:433-443.

15 Bruey JM, Bruey-Sedano N, Newman R, Chandler S, Stehlik C, Reed JC: PAN1/ NALP2/PYPAF2, an inducible inflammatory mediator that regulates NF-kappaB and caspase-1 activation in macrophages. J Biol Chem 2004;279:51897-51907.

16 Fiorentino L, Stehlik C, Oliveira V, Ariza ME, Godzik A, Reed JC: A novel PAAD-containing protein that modulates NF-kappa B induction by cytokines tumor necrosis factor-alpha and interleukin-1beta. J Biol Chem 2002;277:35333-35340.

17 Williams KL, Lich JD, Duncan JA, Reed W, Rallabhandi P, Moore C, Kurtz S, Coffield VM, Accavitti-Loper MA, Su L, Vogel SN, Braunstein M, Ting JP: The CATERPILLER protein monarch-1 is an antagonist of Tolllike receptor-, tumor necrosis factor alpha-, and Mycobacterium tuberculosis-induced pro-inflammatory signals. J Biol Chem 2005; 280:39914-39924.
18 Benko S, Magalhaes JG, Philpott DJ, Girardin SE: NLRC5 limits the activation of inflammatory pathways. J Immunol 2010;185: 1681-1691

19 Moore CB, Bergstralh DT, Duncan JA, Lei Y, Morrison TE, Zimmermann AG, AccavittiLoper MA, Madden VJ, Sun L, Ye Z, Lich JD, Heise MT, Chen Z, Ting JP: NLRX1 is a regulator of mitochondrial antiviral immunity. Nature 2008;451:573-577.

20 Wang Y, Hasegawa M, Imamura R, Kinoshita T, Kondo C, Konaka K, Suda T: PYNOD, a novel Apaf-1/CED4-like protein is an inhibitor of ASC and caspase-1. Int Immunol 2004;16:777-786.

-21 Kinoshita T, Wang Y, Hasegawa M, Imamura $R$, Suda T: PYPAF3, a PYRIN-containing APAF-1-like protein, is a feedback regulator of caspase-1-dependent interleukin-1beta secretion. J Biol Chem 2005;280:21720 21725.

22 Davis BK, Roberts RA, Huang MT, Willingham SB, Conti BJ, Brickey WJ, Barker BR, Kwan M, Taxman DJ, Accavitti-Loper MA, Duncan JA, Ting JP: Cutting edge: NLRC5dependent activation of the inflammasome. J Immunol 2011;186:1333-1337.

23 LeibundGut-Landmann S, Waldburger JM Krawczyk M, Otten LA, Suter T, Fontana A, Acha-Orbea H, Reith W: Mini-review: specificity and expression of CIITA, the master regulator of MHC class II genes. Eur J Immunol 2004;34:1513-1525.

24 Meissner TB, Li A, Biswas A, Lee KH, Liu YJ, Bayir E, Iliopoulos D, van den Elsen PJ, Kobayashi KS: NLR family member NLRC5 is a transcriptional regulator of MHC class I genes. Proc Natl Acad Sci USA 2010;107: 13794-13799.

25 Williams KL, Taxman DJ, Linhoff MW, Reed W, Ting JP: Cutting edge: monarch-1: a pyrin/nucleotide-binding domain/leucinerich repeat protein that controls classical and nonclassical MHC class I genes. J Immunol 2003;170:5354-5358. 
-26 Jounai N, Kobiyama K, Shiina M, Ogata K, Ishii KJ, Takeshita F: NLRP4 negatively regulates autophagic processes through an association with beclin1. J Immunol 2011;186: 1646-1655.

-27 Tong ZB, Gold L, Pfeifer KE, Dorward H, Lee E, Bondy CA, Dean J, Nelson LM: Mater, a maternal effect gene required for early embryonic development in mice. Nat Genet 2000;26:267-268.

28 Murdoch S, Djuric U, Mazhar B, Seoud M, Khan R, Kuick R, Bagga R, Kircheisen R, Ao A, Ratti B, Hanash S, Rouleau GA, Slim R: Mutations in NALP7 cause recurrent hydatidiform moles and reproductive wastage in humans. Nat Genet 2006;38:300-302.

-29 Westerveld GH, Korver CM, van Pelt AM, Leschot NJ, van der Veen F, Repping S, Lombardi MP: Mutations in the testis-specific NALP14 gene in men suffering from spermatogenic failure. Hum Reprod 2006;21: 3178-3184.

-30 Hoffman HM, Mueller JL, Broide DH, Wanderer AA, Kolodner RD: Mutation of a new gene encoding a putative pyrin-like protein causes familial cold autoinflammatory syndrome and Muckle-Wells syndrome. Nat Genet 2001;29:301-305.

- 31 Brydges SD, Mueller JL, McGeough MD, Pena CA, Misaghi A, Gandhi C, Putnam CD, Boyle DL, Firestein GS, Horner AA, Soroosh P, Watford WT, O'Shea JJ, Kastner DL, Hoffman HM: Inflammasome-mediated disease animal models reveal roles for innate but not adaptive immunity. Immunity 2009;30:875887.

-32 Meng G, Zhang F, Fuss I, Kitani A, Strober $\mathrm{W}$ : A mutation in the Nlrp3 gene causing inflammasome hyperactivation potentiates Th17 cell-dominant immune responses. Immunity 2009;30:860-874.

- 33 Martinon F, Petrilli V, Mayor A, Tardivel A, Tschopp J: Gout-associated uric acid crystals activate the NALP3 inflammasome. Nature 2006;440:237-241.

- 34 Hoffman HM, Scott P, Mueller JL, Misaghi A, Stevens S, Yancopoulos GD, Murphy A, Valenzuela DM, Liu-Bryan R: Role of the leucine-rich repeat domain of cryopyrin/ NALP3 in monosodium urate crystal-induced inflammation in mice. Arthritis Rheum 2010;62:2170-2179.

- 35 So A, De Smedt T, Revaz S, Tschopp J: A pilot study of IL-1 inhibition by anakinra in acute gout. Arthritis Res Ther 2007;9:R28.

- 36 Kastbom A, Verma D, Eriksson P, Skogh T, Wingren $G$, Soderkvist P: Genetic variation in proteins of the cryopyrin inflammasome influences susceptibility and severity of rheumatoid arthritis (the Swedish TIRA project). Rheumatology 2008;47:415-417.

-37 Glinsky GV: SNP-guided microRNA maps (MirMaps) of 16 common human disorders identify a clinically accessible therapy reversing transcriptional aberrations of nuclear import and inflammasome pathways. Cell Cycle 2008;7:3564-3576.
Kolly L, Busso N, Palmer G, Talabot-Ayer D, Chobaz V, So A: Expression and function of the NALP3 inflammasome in rheumatoid synovium. Immunology 2010;129:178-185.

-39 Rosengren S, Hoffman HM, Bugbee W, Boyle DL: Expression and regulation of cryopyrin and related proteins in rheumatoid arthritis synovium. Ann Rheum Dis 2005;64: 708-714.

40 Gartlehner G, Hansen RA, Jonas BL, Thieda $\mathrm{P}$, Lohr KN: The comparative efficacy and safety of biologics for the treatment of rheumatoid arthritis: a systematic review and metaanalysis. J Rheumatol 2006;33:23982408.

-41 Hirsch EC, Breidert T, Rousselet E, Hunot S, Hartmann A, Michel PP: The role of glial reaction and inflammation in Parkinson's disease. Ann NY Acad Sci 2003;991:214-228.

42 Ona VO, Li M, Vonsattel JP, Andrews LJ, Khan SQ, Chung WM, Frey AS, Menon AS, Li XJ, Stieg PE, Yuan J, Penney JB, Young AB, Cha JH, Friedlander RM: Inhibition of caspase-1 slows disease progression in a mouse model of Huntington's disease. Nature 1999; 399:263-267.

43 Pasinelli P, Borchelt DR, Houseweart MK, Cleveland DW, Brown RH Jr: Caspase-1 is activated in neural cells and tissue with amyotrophic lateral sclerosis-associated mutations in copper-zinc superoxide dismutase. Proc Natl Acad Sci USA 1998;95:1576315768.

44 Frederick AM, Davis ML, Rice KP: Inhibition of human DNA polymerase beta activity by the anticancer prodrug Cloretazine. Biochem Biophys Res Commun 2009;378:419-423.

- 45 Halle A, Hornung V, Petzold GC, Stewart CR, Monks BG, Reinheckel T, Fitzgerald KA, Latz E, Moore KJ, Golenbock DT: The NALP3 inflammasome is involved in the innate immune response to amyloid-beta. Nat Immunol 2008;9:857-865.

46 Pompl PN, Yemul S, Xiang Z, Ho L, Haroutunian V, Purohit D, Mohs R, Pasinetti GM: Caspase gene expression in the brain as a function of the clinical progression of $\mathrm{Alz}$ heimer disease. Arch Neurol 2003;60:369376.

47 Furlan R, Martino G, Galbiati F, Poliani PL, Smiroldo S, Bergami A, Desina G, Comi G, Flavell R, Su MS, Adorini L: Caspase-1 regulates the inflammatory process leading to autoimmune demyelination. J Immunol 1999; 163:2403-2409.

48 Huang WX, Huang P, Hillert J: Increased expression of caspase-1 and interleukin-18 in peripheral blood mononuclear cells in patients with multiple sclerosis. Mult Scler 2004;10:482-487.

49 Gris D, Ye Z, Iocca HA, Wen H, Craven RR, Gris P, Huang M, Schneider M, Miller SD, Ting JP: NLRP3 plays a critical role in the development of experimental autoimmune encephalomyelitis by mediating Th1 and Th17 responses. J Immunol 2010;185:974981.
50 Shaw PJ, Lukens JR, Burns S, Chi H, McGargill MA, Kanneganti TD: Cutting edge: critical role for PYCARD/ASC in the development of experimental autoimmune encephalomyelitis. J Immunol 2010;184:4610-4614.

-51 Roy N, Mahadevan MS, McLean M, Shutler G, Yaraghi Z, Farahani R, Baird S, BesnerJohnston A, Lefebvre C, Kang X, et al: The gene for neuronal apoptosis inhibitory protein is partially deleted in individuals with spinal muscular atrophy. Cell 1995;80:167178.

52 Watihayati MS, Fatemeh $\mathrm{H}$, Marini M, Atif $\mathrm{AB}$, Zahiruddin WM, Sasongko TH, Tang $\mathrm{TH}$, Zabidi-Hussin ZA, Nishio H, Zilfalil BA: Combination of SMN2 copy number and NAIP deletion predicts disease severity in spinal muscular atrophy. Brain Dev 2009;31: 42-45.

53 Christie LA, Su JH, Tu CH, Dick MC, Zhou J, Cotman CW: Differential regulation of inhibitors of apoptosis proteins in Alzheimer's disease brains. Neurobiol Dis 2007;26:165173.

54 Crocker SJ, Wigle N, Liston P, Thompson CS, Lee CJ, Xu D, Roy S, Nicholson DW, Park DS, MacKenzie A, Korneluk RG, Robertson GS: NAIP protects the nigrostriatal dopamine pathway in an intrastriatal 6-OHDA rat model of Parkinson's disease. Eur J Neurosci 2001;14:391-400.

-55 Karimpour S, Davoodi J, Ghahremani MH Integrity of ATP binding site is essential for effective inhibition of the intrinsic apoptosis pathway by NAIP. Biochem Biophys Res Commun 2011;407:158-162.

-56 Wassel CL, Lange LA, Keating BJ, Taylor KC, Johnson AD, Palmer C, Ho LA, Smith NL, Lange EM, Li Y, Yang Q, Delaney JA, Tang W, Tofler G, Redline S, Taylor HA, Jr, Wilson JG, Tracy RP, Jacobs DR Jr, Folsom AR, Green D, O'Donnell CJ, Reiner AP: Association of genomic loci from a cardiovascular gene SNP array with fibrinogen levels in European Americans and African-Americans from six cohort studies: the Candidate Gene Association Resource (CARe). Blood 2011; 117:268-275.

57 Kawaguchi M, Takahashi M, Hata T, Kashima Y, Usui F, Morimoto H, Izawa A, Takahashi Y, Masumoto J, Koyama J, Hongo M, Noda T, Nakayama J, Sagara J, Taniguchi S, Ikeda U: Inflammasome activation of cardiac fibroblasts is essential for myocardial ischemia/reperfusion injury. Circulation 2011;123:594-604.

58 Yajima N, Takahashi M, Morimoto H, Shiba Y, Takahashi Y, Masumoto J, Ise H, Sagara J, Nakayama J, Taniguchi S, Ikeda U: Critical role of bone marrow apoptosis-associated speck-like protein, an inflammasome adaptor molecule, in neointimal formation after vascular injury in mice. Circulation 2008; 117:3079-3087.

59 Hansson GK, Hermansson A: The immune system in atherosclerosis. Nat Immunol 2011;12:204-212. 
60 Duewell P, Kono H, Rayner KJ, Sirois CM, Vladimer G, Bauernfeind FG, Abela GS, Franchi L, Nunez G, Schnurr M, Espevik T, Lien E, Fitzgerald KA, Rock KL, Moore KJ, Wright SD, Hornung V, Latz E: NLRP3 inflammasomes are required for atherogenesis and activated by cholesterol crystals. Nature 2010;464:1357-1361.

-61 Freigang S, Ampenberger F, Spohn G, Heer S, Shamshiev AT, Kisielow J, Hersberger M, Yamamoto M, Bachmann MF, Kopf M: Nrf2 is essential for cholesterol crystal-induced inflammasome activation and exacerbation of atherosclerosis. Eur J Immunol 2011;41: 2040-2051.

-62 Meissner F, Molawi K, Zychlinsky A: Superoxide dismutase 1 regulates caspase- 1 and endotoxic shock. Nat Immunol 2008;9:866872.

-63 Tassi S, Carta S, Vene R, Delfino L, Ciriolo MR, Rubartelli A: Pathogen-induced interleukin-1beta processing and secretion is regulated by a biphasic redox response. J Immunol 2009; 183:1456-1462.

64 Davis BK, Wen H, Ting JP: The inflammasome NLRs in immunity, inflammation, and associated diseases. Ann Rev Immunol 2011; 29:707-735.

65 Dieude P, Guedj M, Wipff J, Ruiz B, Riemekasten G, Airo P, Melchers I, Hachulla E, Cerinic MM, Diot E, Hunzelmann N, Caramaschi P, Sibilia J, Tiev K, Mouthon L, Riccieri V, Cracowski JL, Carpentier PH, Distler J, Amoura Z, Tarner I, Avouac J, Meyer O, Kahan A, Boileau C, Allanore Y: NLRP1 influences the systemic sclerosis phenotype: a new clue for the contribution of innate immunity in systemic sclerosis-related fibrosing alveolitis pathogenesis. Ann Rheum Dis 2011;70:668-674.

-66 Couillin I, Vasseur V, Charron S, Gasse P, Tavernier M, Guillet J, Lagente V, Fick L, Jacobs M, Coelho FR, Moser R, Ryffel B: IL$1 \mathrm{R} 1 / \mathrm{MyD} 88$ signaling is critical for elastaseinduced lung inflammation and emphysema. J Immunol 2009;183:8195-8202.

-67 Gasse P, Mary C, Guenon I, Noulin N, Charron S, Schnyder-Candrian S, Schnyder B, Akira S, Quesniaux VF, Lagente V, Ryffel B, Couillin I: IL-1R1/MyD88 signaling and the inflammasome are essential in pulmonary inflammation and fibrosis in mice. J Clin Invest 2007;117:3786-3799.

68 Gasse P, Riteau N, Charron S, Girre S, Fick L, Petrilli V, Tschopp J, Lagente V, Quesniaux VF, Ryffel B, Couillin I: Uric acid is a danger signal activating NALP3 inflammasome in lung injury inflammation and fibrosis. Am J Respir Crit Care Med 2009;179:903-913.

69 Kool M, Willart MA, van Nimwegen M, Bergen I, Pouliot P, Virchow JC, Rogers N, Osorio F, Reis ESC, Hammad H, Lambrecht BN: An unexpected role for uric acid as an inducer of T helper 2 cell immunity to inhaled antigens and inflammatory mediator of allergic asthma. Immunity 2011;34:527-540.
Besnard AG, Guillou N, Tschopp J, Erard F, Couillin I, Iwakura Y, Quesniaux V, Ryffel B, Togbe D: NLRP3 inflammasome is required in murine asthma in the absence of aluminum adjuvant. Allergy 2011;66:1047-1057.

-71 Dostert C, Petrilli V, Van Bruggen R, Steele C, Mossman BT, Tschopp J: Innate immune activation through Nalp3 inflammasome sensing of asbestos and silica. Science 2008 ; 320:674-677.

72 Cassel SL, Eisenbarth SC, Iyer SS, Sadler JJ, Colegio OR, Tephly LA, Carter AB, Rothman PB, Flavell RA, Sutterwala FS: The Nalp3 inflammasome is essential for the development of silicosis. Proc Natl Acad Sci USA 2008;105:9035-9040.

73 Yazdi AS, Guarda G, Riteau N, Drexler SK, Tardivel A, Couillin I, Tschopp J: Nanoparticles activate the NLR pyrin domain containing 3 (Nlrp3) inflammasome and cause pulmonary inflammation through release of IL-1alpha and IL-1beta. Proc Natl Acad Sci USA 2010;107:19449-19454.

74 McDonald B, Pittman K, Menezes GB, Hirota SA, Slaba I, Waterhouse CC, Beck PL, Muruve DA, Kubes P: Intravascular danger signals guide neutrophils to sites of sterile inflammation. Science 2010;330:362-366.

75 Imaeda AB, Watanabe A, Sohail MA, Mahmood S, Mohamadnejad M, Sutterwala FS, Flavell RA, Mehal WZ: Acetaminophen-induced hepatotoxicity in mice is dependent on Tlr9 and the Nalp3 inflammasome. J Clin Invest 2009;119:305-314.

76 Williams CD, Antoine DJ, Shaw PJ, Benson C, Farhood A, Williams DP, Kanneganti TD, Park BK, Jaeschke H: Role of the Nalp3 inflammasome in acetaminophen-induced sterile inflammation and liver injury. Toxicol Appl Pharmacol 2011;252:289-297.

77 Watanabe A, Sohail MA, Gomes DA, Hashmi A, Nagata J, Sutterwala FS, Mahmood S, Jhandier MN, Shi Y, Flavell RA, Mehal WZ: Inflammasome-mediated regulation of hepatic stellate cells. Am J Physiol Gastrointest Liver Physiol 2009;296:G1248-G1257.

78 Masters SL, Dunne A, Subramanian SL, Hull RL, Tannahill GM, Sharp FA, Becker C, Franchi L, Yoshihara E, Chen Z, Mullooly N, Mielke LA, Harris J, Coll RC, Mills KH, Mok KH, Newsholme P, Nunez G, Yodoi J, Kahn SE, Lavelle EC, O'Neill LA: Activation of the NLRP3 inflammasome by islet amyloid polypeptide provides a mechanism for enhanced IL-1beta in type 2 diabetes. Nat Immunol 2010;11:897-904.

79 Stienstra R, Joosten LA, Koenen T, van Tits B, van Diepen JA, van den Berg SA, Rensen PC, Voshol PJ, Fantuzzi G, Hijmans A, Kersten S, Muller M, van den Berg WB, van Rooijen N, Wabitsch M, Kullberg BJ, van der Meer JW, Kanneganti T, Tack CJ, Netea MG: The inflammasome-mediated caspase- 1 activation controls adipocyte differentiation and insulin sensitivity. Cell Metab 2010;12: 593-605.
80 Vandanmagsar B, Youm YH, Ravussin A, Galgani JE, Stadler K, Mynatt RL, Ravussin E, Stephens JM, Dixit VD: The NLRP3 inflammasome instigates obesity-induced inflammation and insulin resistance. Nat Med 2011;17:179-188.

81 Wen H, Gris D, Lei Y, Jha S, Zhang L, Huang MT, Brickey WJ, Ting JP: Fatty acid-induced NLRP3-ASC inflammasome activation interferes with insulin signaling. Nat Immunol 2011;12:408-415.

82 Joosten LA, Netea MG, Mylona E, Koenders MI, Malireddi RK, Oosting M, Stienstra R, van de Veerdonk FL, Stalenhoef AF, Giamarellos-Bourboulis EJ, Kanneganti TD, van der Meer JW: Engagement of fatty acids with Toll-like receptor 2 drives interleukinlbeta production via the ASC/caspase 1 pathway in monosodium urate monohydrate crystal-induced gouty arthritis. Arthritis Rheum 2010;62:3237-3248.

83 Csak T, Ganz M, Pespisa J, Kodys K, Dolganiuc A, Szabo G: Fatty acid and endotoxin activate inflammasomes in mouse hepatocytes that release danger signals to stimulate immune cells. Hepatology 2011;54:133-144.

84 Goncalves RG, Gabrich L, Rosario A Jr, Takiya CM, Ferreira ML, Chiarini LB, Persechini PM, Coutinho-Silva R, Leite M Jr: The role of purinergic $\mathrm{P} 2 \mathrm{X} 7$ receptors in the inflammation and fibrosis of unilateral ureteral obstruction in mice. Kidney Int 2006; 70:1599-1606.

85 Babelova A, Moreth K, Tsalastra-Greul W, Zeng-Brouwers J, Eickelberg O, Young MF, Bruckner P, Pfeilschifter J, Schaefer RM, Grone HJ, Schaefer L: Biglycan, a danger signal that activates the NLRP3 inflammasome via Toll-like and P2X receptors. J Biol Chem 2009:284:24035-24048.

86 Yamasaki K, Muto J, Taylor KR, Cogen AL, Audish D, Bertin J, Grant EP, Coyle AJ, Misaghi A, Hoffman HM, Gallo RL: NLRP3/ cryopyrin is necessary for interleukin-1beta (IL-1beta) release in response to hyaluronan, an endogenous trigger of inflammation in response to injury. J Biol Chem 2009;284: 12762-12771.

87 Vilaysane A, Chun J, Seamone ME, Wang W, Chin R, Hirota S, Li Y, Clark SA, Tschopp J, Trpkov K, Hemmelgarn BR, Beck PL, Muruve DA: The NLRP3 inflammasome promotes renal inflammation and contributes to CKD. J Am Soc Nephrol 2010;21:1732-1744.

$\$ 88$ Melnikov VY, Ecder T, Fantuzzi G, Siegmund B, Lucia MS, Dinarello CA, Schrier RW, Edelstein CL: Impaired IL-18 processing protects caspase-1-deficient mice from ischemic acute renal failure. J Clin Invest 2001;107:1145-1152.

89 Iyer SS, Pulskens WP, Sadler JJ, Butter LM, Teske GJ, Ulland TK, Eisenbarth SC, Florquin S, Flavell RA, Leemans JC, Sutterwala FS: Necrotic cells trigger a sterile inflammatory response through the Nlrp3 inflammasome. Proc Natl Acad Sci USA 2009;106: 20388-20393. 
90 Shigeoka AA, Mueller JL, Kambo A, Mathison JC, King AJ, Hall WF, Correia Jda S, Ulevitch RJ, Hoffman HM, McKay DB: An inflammasome-independent role for epithelial-expressed Nlrp3 in renal ischemia-reperfusion injury. J Immunol 2010;185:62776285.

-91 Slavova N, Drescher A, Visekruna A, Dullat S, Kroesen AJ, Ritz JP, Buhr HJ: NALP expression in Paneth cells provides a novel track in IBD signaling. Langenbecks Arch Surg 2010;395:351-357.

92 Villani AC, Lemire M, Fortin G, Louis E, Silverberg MS, Collette $\mathrm{C}, \mathrm{Baba} \mathrm{N}$, Libioulle $\mathrm{C}$, Belaiche J, Bitton A, Gaudet D, Cohen A, Langelier D, Fortin PR, Wither JE, Sarfati M, Rutgeerts P, Rioux JD, Vermeire S, Hudson TJ, Franchimont D: Common variants in the NLRP3 region contribute to Crohn's disease susceptibility. Nat Genet 2009;41:71-76.

$\$ 93$ Allen IC, TeKippe EM, Woodford RM, Uronis JM, Holl EK, Rogers AB, Herfarth $\mathrm{HH}$, Jobin C, Ting JP: The NLRP3 inflammasome functions as a negative regulator of tumorigenesis during colitis-associated cancer. J Exp Med 2010;207:1045-1056.

94 Dupaul-Chicoine J, Yeretssian G, Doiron K, Bergstrom KS, McIntire CR, LeBlanc PM, Meunier C, Turbide C, Gros P, Beauchemin N, Vallance BA, Saleh M: Control of intestinal homeostasis, colitis, and colitis-associated colorectal cancer by the inflammatory caspases. Immunity 2010;32:367-378.
95 Hirota SA, Ng J, Lueng A, Khajah M, Parhar K, Li Y, Lam V, Potentier MS, Ng K, Bawa M, McCafferty DM, Rioux KP, Ghosh S, Xavier RJ, Colgan SP, Tschopp J, Muruve D, MacDonald JA, Beck PL: NLRP3 inflammasome plays a key role in the regulation of intestinal homeostasis. Inflamm Bowel Dis 2011;17: 1359-1372.

96 Zaki MH, Boyd KL, Vogel P, Kastan MB, Lamkanfi M, Kanneganti TD: The NLRP3 inflammasome protects against loss of epithelial integrity and mortality during experimental colitis. Immunity 2010;32:379-391.

97 Elinav E, Strowig T, Kau AL, Henao-Mejia J, Thaiss CA, Booth CJ, Peaper DR, Bertin J, Eisenbarth SC, Gordon JI, Flavell RA: NLRP6 inflammasome regulates colonic microbial ecology and risk for colitis. Cell 2011;145:745-757.

98 Chen GY, Liu M, Wang F, Bertin J, Nunez G: A functional role for Nlrp6 in intestinal inflammation and tumorigenesis. J Immunol 2011;186:7187-7194.

99 Alkhateeb A, Qarqaz F: Genetic association of NALP1 with generalized vitiligo in Jordanian Arabs. Arch Dermatol Res 2010;302: 631-634.
00 Jin Y, Mailloux CM, Gowan K, Riccardi SL, LaBerge G, Bennett DC, Fain PR, Spritz RA: NALP1 in vitiligo-associated multiple autoimmune disease. N Engl J Med 2007; 356:1216-1225.

101 Macaluso F, Nothnagel M, Parwez Q, Petrasch-Parwez E, Bechara FG, Epplen JT, Hoffjan S: Polymorphisms in NACHT-LRR (NLR) genes in atopic dermatitis. Exp Dermatol 2007;16:692-698.

102 Sutterwala FS, Ogura Y, Szczepanik M, Lara-Tejero M, Lichtenberger GS, Grant EP, Bertin J, Coyle AJ, Galan JE, Askenase PW, Flavell RA: Critical role for NALP3/CIAS1/ cryopyrin in innate and adaptive immunity through its regulation of caspase-1. Immunity 2006;24:317-327.

103 Watanabe H, Gaide O, Petrilli V, Martinon F, Contassot E, Roques S, Kummer JA, Tschopp J, French LE: Activation of the ILlbeta-processing inflammasome is involved in contact hypersensitivity. J Invest Dermatol 2007;127:1956-1963.

104 Arthur JC, Lich JD, Ye Z, Allen IC, Gris D, Wilson JE, Schneider M, Roney KE, O'Connor BP, Moore CB, Morrison A, Sutterwala FS, Bertin J, Koller BH, Liu Z, Ting JP: Cutting edge: NLRP12 controls dendritic and myeloid cell migration to affect contact hypersensitivity. J Immunol 2010;185: $4515-4519$. 